\title{
SOIL ORGANIC MATTER IN AREAS UNDER YERBA MATE CULTIVATION AND SWINE WASTE APPLICATION
}

\author{
Marcos Gervasio Pereira ${ }^{1 *}$, Roni Fernandes Guareschi ${ }^{2}$, \\ Luiz Alberto Silva Rodrigues Pinto ${ }^{2}$, Talita Santana Matos ${ }^{2}$, Anderson Claiton Ferrari², Cristiane Figueira Silva ${ }^{3}$ \\ ${ }^{1 *}$ Federal Rural University of Rio de Janeiro, Soils Department, Agronomy Institute, Seropédica, Rio de Janeiro, Brazil - e-mail: \\ mgervasiopereira01@gmail.com \\ ${ }^{2}$ Federal Rural University of Rio de Janeiro, Graduate Program in Agronomy - Soil Science, Seropédica, Rio de Janeiro, Brazil - e-mail \\ guareschiecotarelli@hotmail.com; talitasmatos@gmail.com; anderson.rural@hotmail.com \\ ${ }^{3}$ Federal Rural University of Rio de Janeiro, Graduate Program in Environmental and Forest Sciences, Seropédica, Rio de Janeiro, Brazil - e- \\ mail: cfigueirasilva@yahoo.com.br
}

Received for publication: 23/12/2019 - Accepted for publication: 09/10/2020

\begin{abstract}
Resumo
Matéria orgânica do solo em áreas com cultivo de erva-mate e aplicação de dejeto suíno. Avaliou-se o carbono e nitrogênio e suas frações químicas (ácido húmico - HAF, ácido fúlvico - FAF, e humina - HUM) e granulométricas (carbono orgânico particulado - POC, e carbono orgânico associado aos minerais - MAOC) da matéria orgânica em áreas cultivadas com erva-mate (Ilex paraguariensis) com 35 (E35) e 45 (E45) anos de cultivo, além de uma área de mata nativa (NF). Os solos da área de estudo foram classificados como Cambissolo Háplico. As amostras de solo foram coletadas nas camadas de 0-5; 5-10; 10-20 e 20-40 cm. Foi utilizado um delineamento inteiramente casualizado em parcelas subdivididas (3 áreas e 4 profundidades) com 4 repetições. $\mathrm{Na}$ área $\mathrm{E} 45$, por possuir maior tempo de cultivo e adição de adubação orgânica, foram quantificados os maiores teores de TOC, N e POC em comparação à área E35, sendo observado valores similares desses atributos na área de mata em algumas profundidades. As frações de carbono mais estáveis (MAOC e humina) não variaram entre as áreas cultivadas (E35 e E45), no entanto, verificou-se uma redução dessas frações em relação a mata nativa de respectivamente 25 e 14\% (HUM 0-5 cm) e 12 e 21\% (MAOC 5-10 cm).Não se constatou diferença entre as áreas avaliadas para a fração FAF, mas a HAF na área de mata nativa apresentou maiores valores em relação às áreas cultivadas.

Palavras-chave: Carbono orgânico do solo, fracionamentos, cultivo intensivo, Ilex paraguariensis
\end{abstract}

\begin{abstract}
Carbon and nitrogen contents, as well as their chemical fractions (humic acid - HAF, fulvic acid - FAF, humin - HUM) and particle-size fractions (particulate organic carbon - POC, mineral-associated organic carbon MAOC) of organic matter were evaluated in areas cultivated with yerba mate (Ilex paraguariensis) with 35 (E35) and 45 (E45) consecutive years of cultivation, in addition to a native forest area (NF), taken as reference. The soils of the study area were classified as Cambissolo Háplico (Inceptisol). Soil samples were collected at depths of $0.0-0.05,0.05-0.10,0.10-0.20$ and $0.20-0.40 \mathrm{~cm}$. A completely randomized design in split plots (3 areas and 4 depths) with 4 replicates was used. The $\mathrm{E} 45$ area, due to the longer cultivation time and the addition of organic fertilizer, had higher TOC, N and POC contents in comparison to the E35 area, with similar values of these attributes being observed in the forest area at some depths. The most stable carbon fractions (MAOC and HUM) did not vary between cultivated areas (E35 and E45); however, there were reductions of 25 and $14 \%$ (HUM 0-5 cm) and 12 and 21\% (MAOC 5-10 cm) in these fractions, respectively, in comparison to the native forest. There was no difference between the evaluated areas for FAF, but HAF values were higher in the native forest area than in the cultivated areas.

Keywords: Organic soil carbon, fractionations, intensive cultivation, Ilex paraguariensis
\end{abstract}

\section{INTRODUCTION}

In 2018, the world production of yerba mate was 1,853,580,000 tons of green leaves, with Brazil being the main producing country with $939,580,000$ tons ( $50.7 \%$ of the global production). The state of Santa Catarina accounted for $12.88 \%$ of the national production of yerba mate in 2018, producing 121,037,000 tons (IBGE, 2018).

According to Alegre et al. (2007), in addition to the social and economic benefits, yerba mate has great potential to provide environmental services such as carbon sequestration, due to the large volume of biomass produced during its harvest periods (pruning) and recycled carbon in the soil. However, the type of system implemented can contribute to the reduction of the supply of organic material to the soil, as the leaves and branches of yerba mate grown in full sun are usually harvested at intervals of 12 months (PICCOLO et al., 2008). Moreover, the drastic reduction in the supply of organic material in yerba mate areas without soil cover, since the area is kept "clean" through the systematic use of herbicides, does not allow the growth and/or establishment of spontaneous species (DENARDIN et al., 2014). Such characteristics of yerba mate cultivation can affect the dynamics of soil organic matter (SOM) over the years.

FLORESTA, Curitiba, PR, v. 51, n. 3, p. 567-575, jul/set 2021.

Pereira, M. G. et.al.

ISSN eletrônico 1982-4688

DOI: 10.5380/rf.v51 i3. 70954 
Alves et al. (2011) verified that less stable systems such as monocultures contribute to the reduction of carbon stocks when compared to native forest areas or similar environments, such as agroforestry systems, due to the promotion of higher biomass production in these systems, which favor the formation of soil cover and consequently the accumulation of carbon (GAMA-RODRIGUES et al., 2008).

Piccolo et al. (2008) observed that, after 50 years of yerba mate monoculture in Missiones-Argentina, the carbon and nitrogen contents of the $0-15 \mathrm{~cm}$ layer decreased by 42 and $47 \%$, respectively, when compared to the adjacent native forest. Denardin et al. (2014), comparing the values of a yerba mate area (25 years) with those found in a reference area (native forest), found that C losses reached $62 \%$ in the $0-10 \mathrm{~cm}$ layer, $34 \%$ in the $30-40$ $\mathrm{cm}$ layer and $24 \%$ in the $40-50 \mathrm{~cm}$ layer. The authors argue that this reduction of $\mathrm{C}$ and/or $\mathrm{N}$ in the yerba mate areas evaluated results from the lower supply of plant residues, due to the removal of yerba mate branches and leaves, because they constitute the raw material of this crop, as well as due to the continuous mechanical control of weeds (conventional system). Thus, the reduction of $\mathrm{C}$ levels occurred not only due to the reduction of biological processes, but also due to erosion.

Even with these results, there are still few studies in the literature evaluating the dynamics of soil $\mathrm{C}$ and its chemical and physical fractions over the years of cultivation, especially in areas that use organic fertilization with the application of swine waste and/or poultry litter, which end up being another input of SOM, in addition to acting as sources of nutrients.

In the particle-size fractionation of SOM, the organic carbon contents with size of the sand fraction (diameter $\geq 53 \mu \mathrm{m}$ ) (particulate organic carbon - POC) and that associated with the silt and clay fractions (diameter $<53 \mu \mathrm{m}$ ) (mineral-associated organic carbon - MAOC) (BATISTA et al., 2013) are quantified. POC is a labile fraction and has high sensitivity to changes caused by management (CARMO et al., 2012; BATISTA et al., 2013; GAZOLLA et al., 2015; BEUTLER et al., 2016), while MAOC is more recalcitrant, showing a slow cycling, which makes it a more stable fraction and with less sensitivity to changes in the soil.

When evaluating the dynamics of total C, POC and MAOC in a Nitossolo (Ultisol) in Concórdia-SC, in an area of yerba mate with 20 years of successive cultivation, Rauber et al. (2017) found smaller amounts of these fractions when compared to an adjacent native forest. Similarly, Andrade et al. (2016) evaluated the effect of the application of organic fertilizers in areas with 20 years of yerba mate monoculture in a Nitossolo Vermelho (Ultisol) and also found lower contents of $\mathrm{C}, \mathrm{POC}$ and MAOC compared to a native forest.

As for humic substances, fulvic acids (C-FAF), humic acids (C-HAF) and humin (C-HUM), the interactions of these fractions with soil minerals influence the dynamics of $\mathrm{C}$ in the soil, favoring its maintenance and stock in the soil (SANTOS et al., 2013). However, there are few studies in the literature showing the dynamics of these fractions in the soil in yerba mate areas. The hypothesis of this study is that the addition of swine waste will promote changes in the organic matter compartments as a function of the time of adoption of this form of management.

In view of the above, the objective of this study was to evaluate carbon and nitrogen, as well as their chemical fractions (humic acid - HAF, fulvic acid - FAF, humin - HUM) and particle-size fractions (particulate organic carbon - POC, mineral-associated organic carbon - MAOC) of organic matter in samples of a Cambissolo Háplico (Inceptisol) cultivated with yerba mate (Ilex paraguariensis) with 35 and 45 years of cultivation, with annual application of swine waste, in addition to a native forest area (NF) taken as reference.

\section{MATERIAL AND METHODS}

The study was carried out in the municipality of Presidente Castello Branco - SC, Brazil $\left(27^{\circ} 13^{\prime} 17^{\prime \prime} \mathrm{S}\right.$, $51^{\circ} 48^{\prime} 40^{\prime \prime} \mathrm{W}$, altitude of $452 \mathrm{~m}$ ), in the Alto Uruguai Catarinense region. According to the Köppen-Geiger classification, the climate of the region is humid subtropical $(\mathrm{Cfa})$, with an average temperature of $20.6^{\circ} \mathrm{C}$ and an average annual rainfall of $1711 \mathrm{~mm}$ (IBGE, 2010).

Soil samples were collected in two areas of yerba mate (Ilex paraguariensis) monoculture with 35 (E35) and 45 (E45) years of consecutive crops, in addition to an adjacent area of native forest, taken as reference, with approximately 0.5 ha. The management practices of the two areas of yerba mate (E35 and E45) consist of intensive application of animal waste (swine manure) at an annual rate of $400 \mathrm{~m}^{3} \mathrm{ha}^{-1}$, carried out at 90-day intervals, which has been performed for twenty and fifteen years in E45 and E35, respectively. Weed control with mowing and herbicide application is also carried out in the areas. The reference native forest area was evaluated in order to represent a natural state of the soil, without anthropic interference of the management.

The soil of the areas was classified as Cambissolo Háplico (Inceptisol). Four composite samples were collected in the layers of $0-5,5-10,10-20$ and $20-40 \mathrm{~cm}$ in zig zag, $75 \%$ of the samples collected between rows and $25 \%$ in the planting rows. The soil samples were air dried, pounded to break up clods and passed through a 2-mm-mesh sieve, obtaining the air-dried fine earth (ADFE), which was subjected to chemical characterization and particle-size analysis (Teixeira et al., 2011) (Table 1). 
Table 1. Chemical and particle-size analysis of the evaluated areas.

Tabela 1. Análise química e granulométrica das áreas avaliadas.

\begin{tabular}{|c|c|c|c|c|c|c|c|c|c|c|}
\hline \multirow[b]{2}{*}{ *Areas } & \multirow[t]{2}{*}{$\mathbf{p H}$ water } & $\mathbf{C a}$ & Mg & $\mathbf{K}$ & $\mathbf{H}+\mathbf{A l}$ & Al & $\mathbf{P}$ & Sand & Silt & Clay \\
\hline & & \multicolumn{5}{|c|}{ 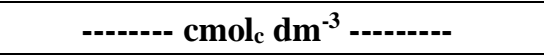 } & $\mathrm{mg} \mathrm{kg}^{-1}$ & \multicolumn{3}{|c|}{$\mathrm{g} \mathrm{kg}^{-1}$} \\
\hline & \multicolumn{10}{|c|}{ - } \\
\hline E35 & 4.5 & 1.5 & 0.7 & 0.3 & 7.2 & 0.9 & 36.3 & 159 & 291 & 550 \\
\hline E45 & 5.1 & 3.3 & 2.0 & 0.2 & 9.5 & 0.8 & 15.7 & 197 & 408 & 395 \\
\hline \multirow[t]{2}{*}{ NF } & 5.3 & 5.8 & 2.6 & 0.1 & 7.1 & 0.2 & 35.3 & 290 & 38 & 328 \\
\hline & & \multicolumn{9}{|c|}{ - $5-10$ cm - } \\
\hline E35 & 4.4 & 1.4 & 0.9 & 0.1 & 12.7 & 1.0 & 21.8 & 146 & 275 & 579 \\
\hline E45 & 4.9 & 2.5 & 0.9 & 0.1 & 8.5 & 0.4 & 14.4 & 217 & 343 & 441 \\
\hline \multirow[t]{2}{*}{$\mathrm{NF}$} & 5.4 & 5.2 & 2.8 & 0.1 & 7.8 & 0.2 & 23.6 & 331 & 328 & 341 \\
\hline & & \multicolumn{9}{|c|}{------------------ 10-20 cm ----------------------- } \\
\hline E35 & 4.3 & 1.2 & 0.7 & 0.1 & 12.9 & 1.1 & 12.4 & 126 & 325 & 550 \\
\hline E45 & 5.1 & 2.4 & 1.8 & 0.1 & 7.6 & 0.3 & 6.8 & 211 & 339 & 450 \\
\hline \multirow[t]{2}{*}{ NF } & 5.1 & 2.4 & 1.8 & 0.1 & 7.6 & 0.3 & 6.8 & 211 & 339 & 450 \\
\hline & \multicolumn{10}{|c|}{ - $20-40$ cm י- י- } \\
\hline E35 & 4.4 & 0.9 & 0.5 & 0.1 & 11.1 & 1.3 & 7.1 & 130 & 290 & 581 \\
\hline E45 & 5.1 & 2.4 & 0.9 & 0.1 & 6.2 & 0.4 & 5.3 & 159 & 383 & 458 \\
\hline $\mathrm{NF}$ & 5.1 & 2.4 & 0.9 & 0.1 & 6.2 & 0.4 & 5.3 & 159 & 383 & 458 \\
\hline
\end{tabular}

* E35 = yerba mate with 35 years of cultivation; $\mathrm{E} 45=$ yerba mate with 45 years of cultivation; $\mathrm{NF}=$ native forest area taken as reference.

Total organic carbon (TOC) was determined by the wet oxidation method, with external heating, proposed by Yeomans and Bremner (1988). Total nitrogen (TN) was determined by the Kjeldahl method (BREMNER; MULVANEY, 1982).

The particle-size fractionation of SOM was performed according to the method described by Cambardella and Elliot (1992). Approximately $20 \mathrm{~g}$ of soil and $60 \mathrm{~mL}$ of sodium hexametaphosphate solution $\left(5 \mathrm{~g} \mathrm{~L}^{-1}\right)$ were stirred for 15 hours in a horizontal shaker. Then, the suspension was passed through a $53-\mu \mathrm{m}-\mathrm{mesh}$ sieve. The material retained on the sieve (particulate organic carbon - POC) was dried in an oven at $50{ }^{\circ} \mathrm{C}$, quantified in relation to its mass, ground in porcelain mortar and analyzed for organic carbon content as described by Yeomans and Bremner (1988). Mineral-associated organic carbon (MAOC) was obtained from the difference between TOC and POC.

Extraction and chemical fractionation of soil samples were performed using the differential solubility technique (SWIFT, 1996), with adaptation of Benites et al. (2003), obtaining organic carbon in the fulvic acid fraction (FAF), humic acid fraction (HAF) and humin (HUM). Quantitative determination of organic carbon in FAF and $\mathrm{HAF}$ was performed using aliquots of $5.0 \mathrm{~mL}$ of extract, $1.0 \mathrm{~mL}$ of potassium dichromate $\left(0.042 \mathrm{~mol} \mathrm{~L}^{-}\right.$ $\left.{ }^{1}\right)$ and $5.0 \mathrm{~mL}$ of concentrated $\mathrm{H}_{2} \mathrm{SO}_{4}$, in a digestor block at $150{ }^{\circ} \mathrm{C}(30 \mathrm{~min})$ and titration with ammoniacal ferrous sulfate $\left(0.0125 \mathrm{~mol} \mathrm{~L}^{-1}\right)$. In the residue, organic carbon was determined in the HUM fraction, after drying the material in an oven at $65{ }^{\circ} \mathrm{C}$ (complete drying) and adding $5.0 \mathrm{~mL}$ of potassium dichromate $\left(0.1667 \mathrm{~mol} \mathrm{~L}^{-1}\right)$ and $10.0 \mathrm{~mL}$ of concentrated $\mathrm{H}_{2} \mathrm{SO}_{4}$, in a digester block at $150^{\circ} \mathrm{C}(30 \mathrm{~min})$, and titration with ferrous sulfate $(0.25 \mathrm{~mol}$ $\mathrm{L}^{-1}$ ) (YEOMANS; BREMNER, 1988).

All data were evaluated for normality of the residuals (Shapiro Wilk) and homoscedasticity of the data (Cochran and Bartlett test). Subsequently, the results were analyzed as a completely randomized design (CRD) with four replicates for each area and layer, being subjected to analysis of variance with application of F Test and comparison of means by Tukey test at 5\% probability level, using the statistical program SISVAR 4.3 (FERREIRA, 2000). Principal component analysis (PCA) was also performed for each layer evaluated, using the PAST program.

\section{RESULTS}

In all areas there were reductions in TOC and TN contents in subsurface, with no significant difference at the 20-40 cm depth (Table 2). Higher TOC contents were also found in the native forest area (NF) compared to the areas E35 $(0-10 \mathrm{~cm})$ and E45 $(5-10 \mathrm{~cm})($ Table 2). The TN content in the forest area was also higher than in the yerba mate plantations (E35 and E45) (Table 2). 
Table 2. Total organic carbon (TOC), total nitrogen (TN) and particle-size and humic fractions of SOM in areas under yerba mate cultivation and swine waste application in Santa Catarina, Brazil.

Tabela 2. Carbono orgânico total (TOC), nitrogênio total (TN) e frações granulométricas e húmicas da SOM em áreas sob cultivo de erva-mate e aplicação de dejeto suíno em Santa Catarina.

\begin{tabular}{|c|c|c|c|c|c|c|c|}
\hline \multirow{3}{*}{ Areas } & TOC & TN & POC & MAOC & FAF & HAF & HUM \\
\hline & \multicolumn{7}{|c|}{ - } \\
\hline & \multicolumn{7}{|c|}{ 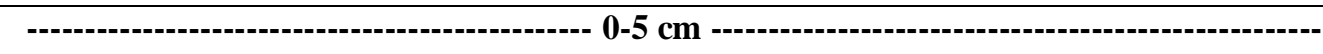 } \\
\hline E35 & $49.49 \mathrm{~b}$ & $4.37 \mathrm{c}$ & $2.50 \mathrm{c}$ & $46.51^{\mathrm{ns}}$ & $4.45^{\mathrm{ns}}$ & $4.53 \mathrm{~b}$ & $20.18 \mathrm{~b}$ \\
\hline E45 & $53.98 \mathrm{ab}$ & $7.19 \mathrm{~b}$ & $3.51 \mathrm{~b}$ & 49.93 & 4.34 & $1.79 \mathrm{c}$ & $23.12 \mathrm{ab}$ \\
\hline $\mathrm{NF}$ & $57.06 \mathrm{a}$ & $9.06 \mathrm{a}$ & $5.17 \mathrm{a}$ & 50.15 & 4.50 & $37.18 \mathrm{a}$ & $26.99 \mathrm{a}$ \\
\hline \multirow[t]{2}{*}{$\mathrm{CV}(\%)$} & 6.29 & 8.28 & 6.10 & 5.42 & 10.51 & 14.64 & 10.93 \\
\hline & \multicolumn{7}{|c|}{ 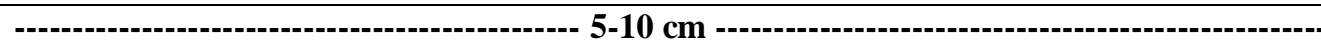 } \\
\hline E35 & $44.82^{\mathrm{ns}}$ & $3.65 \mathrm{~b}$ & $1.65 \mathrm{~b}$ & $39.27 \mathrm{ab}$ & $3.96^{\mathrm{ns}}$ & $3.03 \mathrm{~b}$ & $18.26^{\mathrm{ns}}$ \\
\hline E45 & 41.21 & $5.42 \mathrm{a}$ & $1.98 \mathrm{~b}$ & $35.25 \mathrm{~b}$ & 3.65 & $3.95 \mathrm{~b}$ & 17.49 \\
\hline $\mathrm{NF}$ & 47.99 & $6.11 \mathrm{a}$ & $2.76 \mathrm{a}$ & $44.76 \mathrm{a}$ & 3.67 & $25.03 \mathrm{a}$ & 18.99 \\
\hline \multirow[t]{2}{*}{ CV (\%) } & 7.06 & 10.13 & 9.14 & 8.35 & 14.28 & 18.81 & 13.06 \\
\hline & \multicolumn{7}{|c|}{ 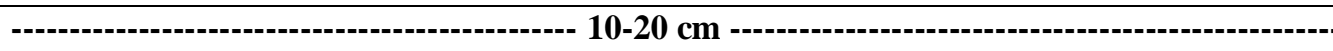 } \\
\hline E35 & $35.79^{\mathrm{ns}}$ & $3.60 \mathrm{~b}$ & $1.17 \mathrm{c}$ & $34.62^{\mathrm{ns}}$ & $3.80^{\mathrm{ns}}$ & $2.90 \mathrm{~b}$ & $14.82^{\mathrm{ns}}$ \\
\hline E45 & 32.92 & $3.97 \mathrm{ab}$ & $1.67 \mathrm{~b}$ & 31.35 & 3.55 & $3.57 \mathrm{~b}$ & 13.51 \\
\hline NF & 31.39 & $4.46 \mathrm{a}$ & $2.05 \mathrm{a}$ & 24.86 & 3.60 & $30.61 \mathrm{a}$ & 14.03 \\
\hline \multirow[t]{2}{*}{$\mathrm{CV}(\%)$} & 14.41 & 6.37 & 10.87 & 17.53 & 10.71 & 13.04 & 7.57 \\
\hline & \multicolumn{7}{|c|}{ 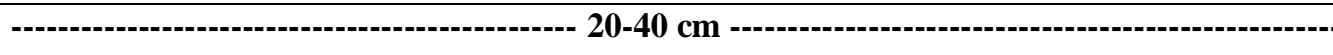 } \\
\hline E35 & $22.14^{\mathrm{ns}}$ & $3.12^{\mathrm{ns}}$ & $0.94 \mathrm{~b}$ & $21.98^{\mathrm{ns}}$ & $2.93^{\mathrm{ns}}$ & $1.39 \mathrm{~b}$ & $12.18^{\mathrm{ns}}$ \\
\hline E45 & 23.38 & 3.75 & $1.01 \mathrm{ab}$ & 22.37 & 2.42 & $2.21 \mathrm{~b}$ & 10.94 \\
\hline $\mathrm{NF}$ & 22.71 & 3.49 & $1.40 \mathrm{a}$ & 18.14 & 2.54 & $20.59 \mathrm{a}$ & 10.71 \\
\hline $\mathrm{CV}(\%)$ & 17.01 & 12.86 & 17.50 & 13.00 & 9.63 & 5.92 & 9.28 \\
\hline
\end{tabular}

Means followed by the same lowercase letter in the column indicate no difference between the areas for the same layer (Tukey test, at 5\% probability level) and ${ }^{\text {ns }}$ not significant at $5 \%$ probability level. E35: Yerba mate with 35 years of cultivation; E45: Yerba mate with 45 years of cultivation; NF: Native forest area taken as a reference; POC: Particulate organic carbon; MAOC: Mineral-associated organic carbon; FAF: Fulvic acid fraction; HAF: Humic acid fraction; HUM: Humin fraction; and CV: Coefficient of variation.

Among the cultivated areas, it was observed that the oldest area (E45) had the highest TOC contents at all depths, and the values were similar to those verified in the native forest area. The lowest values for this attribute were observed in the E35 area. As for TN, the highest values were found in the $0-5 \mathrm{~cm}$ layer in the forest area. For the other layers, there were no differences between the forest area and E45.

Regarding the organic carbon contents of the particle-size fractions of SOM, the area of native forest had higher POC contents compared to the E35 area for all depths evaluated and compared to the E45 area up to the 10-20 cm layer (Table 2). In the comparison between the areas, higher POC contents in the E45 area in comparison to E35 were observed only in the layers of 0-5 and 10-20 cm (Table 2). As for the mineral-associated organic carbon (MAOC), the 5-10 cm layer stood out with the highest values in the NF area, followed by the E35 area (Table 2).

As for MAOC, the highest $(5-10 \mathrm{~cm})$ and lowest $(20-40 \mathrm{~cm})$ contents occurred in the forest area. Similar results of MAOC were also observed between the cultivated areas $(0-40 \mathrm{~cm})$, with values similar to those quantified in the native forest area $(0-05$ and $20-40 \mathrm{~cm})$.

Regarding the organic carbon contents of the chemical fractions of SOM, there was a reduction in the fulvic acid fraction (FAF) in subsurface, without significant differences between the evaluated areas (Table 2). The native forest area had higher values of the humic acid fraction (HAF) $(0-40 \mathrm{~cm})$ compared to the cultivated areas.

Among the cultivated areas, there was virtually no difference for HAF, except in the surface layer $(0-5$ $\mathrm{cm}$ ), in which the E35 area had the highest contents of this fraction, compared to E45 (Table 2). Regarding the humin fraction (HUM) in the 0-5 cm layer, differences were observed between the areas, with higher values in the forest and E45 areas, and these data were consistent with the pattern observed for the C contents (Table 2).

In principal component analysis (PCA), integrating SOM compartments, the first two axes (Axis 1 and Axis 2) were considered, which best explain the variances of the data in the layers of 0-5, 5-10, 10-20 and 20-40 
$\mathrm{cm}$ (Figure 1), whose cumulative percentages of variance were $70.04 \%, 66.74 \%, 72.40 \%$ and $52.16 \%$, respectively (Figure 1). The separation between the E35 area and the native forest area along axis 1 (main axis) was observed more clearly (Figure 1), while the E45 area is more dispersed, with tendency to intermediate positions in comparison to E35 and the native forest area, in most of the evaluated layers (Figure 1A, 1C and 1D). The variables that most contributed to the discrimination of the areas in the different layers were: TOC $(0-5 \mathrm{~cm}), \mathrm{TN}(0-5 ; 5-10$; $10-20 \mathrm{~cm})$, POC (0-5; 5-10; 10-20; 20-40 cm), MAOC (0-5; 5-10; 10-20; 20-40 cm), FAF (10-20 cm); HAF (0-5; $5-10 ; 10-20 ; 20-40 \mathrm{~cm})$ and HUM $(0-5 \mathrm{~cm})$, whose relations with axes 1 or 2 were $> \pm 0.70$ (Table 3 ).
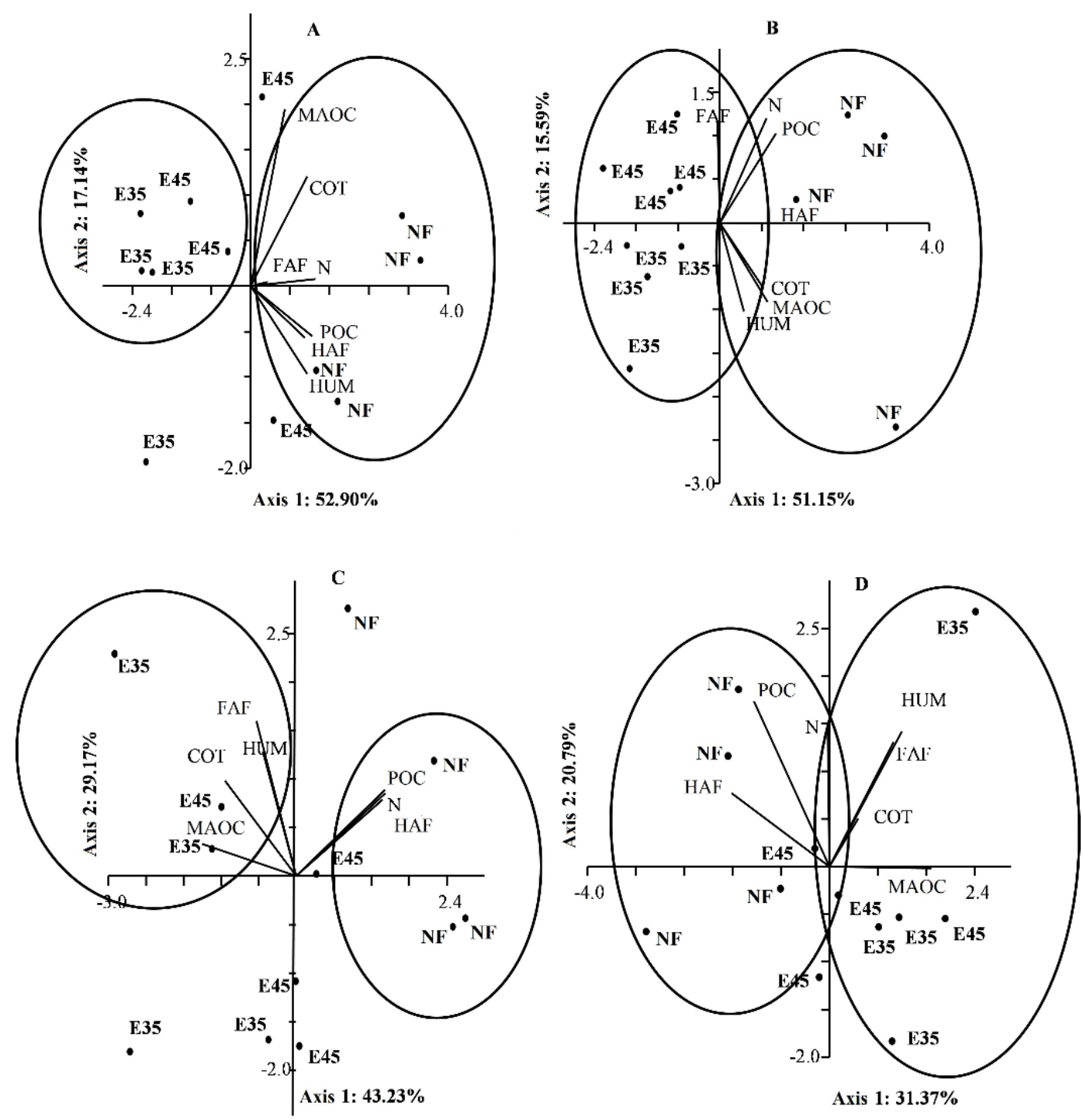

Figure 1. Principal component analysis (PCA) integrating the content of total organic carbon (TOC), total nitrogen (TN) and particle-size and humic fractions of SOM in areas under yerba mate cultivation and swine waste application in Santa Catarina, Brazil, in the layers 0-5 (A), 5-10 (B), 10-20 (C) and 20-40 cm (D). E35: Yerba mate with 35 years of cultivation; E45: Yerba mate with 45 years of cultivation; NF: Native forest area taken as a reference; POC: Particulate organic carbon; MAOC: Mineral-associated organic carbon; FAF: Fulvic acid fraction; HAF: Humic acid fraction; and HUM: Humin fraction.

Figura 1. Análise de componentes principais (PCA) integrando o conteúdo de carbono orgânico total (TOC), nitrogênio total (TN) e as frações granulométricas e húmicas da SOM em áreas sob cultivo de ervamate e aplicação de dejeto suíno em Santa Catarina, nas camadas de 0-5 (A), 5-10 (B), 10-20 (C) e 20$40 \mathrm{~cm}$ (D). E35: Erva-mate com 35 anos de cultivo; E45: Erva-mate com 45 anos de cultivo; NF: Área de mata nativa tomada como referência; POC: Carbono orgânico particulado; MAOC: Carbono orgânico associado aos minerais; FAF: Fração ácido fúlvico; HAF: Fração ácido húmico; e HUM: Fração humina. 
Table 3. Relative contribution of the different attributes associated with the principal components in the layers of 0-5, 5-10, 1020 and $20-40 \mathrm{~cm}$ in areas under yerba mate cultivation and swine waste application in Santa Catarina, Brazil.

Tabela 3. Contribuição relativa dos diferentes atributos associados aos componentes principais 1 e 2, nas camadas de 0-5, 510, 10-20 e 20-40 cm em áreas sob cultivo de erva-mate e aplicação de dejeto suíno em Santa Catarina.

\begin{tabular}{ccccccccc}
\hline \multirow{2}{*}{ Attributes } & \multicolumn{2}{c}{$\mathbf{0 - 5} \mathbf{~ c m}$} & \multicolumn{2}{c}{$\mathbf{5 - 1 0} \mathbf{~ c m}$} & \multicolumn{2}{c}{$\mathbf{1 0 - 2 0} \mathbf{~ c m}$} & \multicolumn{2}{c}{$\mathbf{2 0 - 4 0} \mathbf{~ c m}$} \\
\cline { 2 - 8 } & Axis 1 & Axis 2 & Axis 1 & Axis 2 & Axis 1 & Axis 2 & Axis 1 & Axis 2 \\
\hline TOC & 0.84 & 0.50 & 0.67 & -0.33 & -0.66 & 0.47 & 0.24 & 0.21 \\
TN & 0.96 & 0.03 & 0.72 & 0.53 & 0.83 & 0.41 & -0.01 & 0.60 \\
POC & 0.96 & -0.23 & 0.86 & 0.46 & 0.82 & 0.43 & -0.63 & 0.71 \\
MAOC & 0.51 & 0.81 & 0.73 & -0.41 & -0.88 & 0.16 & 0.85 & -0.01 \\
FAF & 0.25 & 0.02 & -0.04 & 0.52 & -0.37 & 0.76 & 0.53 & 0.54 \\
HAF & 0.81 & -0.24 & 0.97 & 0.00 & 0.80 & 0.38 & -0.81 & 0.32 \\
HUM & 0.84 & -0.40 & 0.37 & -0.45 & -0.31 & 0.62 & 0.60 & 0.58
\end{tabular}

TOC: Total organic carbon; TN: Total nitrogen; POC: Particulate organic carbon; MAOC: Mineral-associated organic carbon; FAF: Fulvic acid fraction; HAF: Humic acid fraction; and HUM: Humin fraction.

TOC: Carbono orgânico total; TN: Nitrogênio total; POC: Carbono orgânico particulado; MAOC: Carbono orgânico associado aos minerais; FAF: Fração ácido fúlvico; HAF: Fração ácido húmico; e HUM: Fração humina

\section{DISCUSSION}

The results verified for TOC and TN in the 0-20 cm layer in all areas were due to the reduction in the supply of organic material in subsurface by plants. Several studies in the literature evaluating yerba mate areas also found this pattern (PICCOLO et al., 2008; DENARDIN et al., 2014). As for the higher contents of TOC and $\mathrm{TN}$ in the native forest area (NF) compared to yerba mate areas (E35 and E45), the authors attribute these results to the higher density and diversity of individuals, greater size of plants, besides older age, which contribute to higher biomass and input of organic material in the soil, which consequently favors greater accumulations of TOC and $\mathrm{N}$ compared to the other areas. The authors also argue that this reduction of $\mathrm{C}$ and/or $\mathrm{N}$ in yerba mate areas results from the lower supply of plant residues due to the removal of yerba mate branches and leaves, as well as due to the continuous mechanical control of weeds (conventional system). Thus, $\mathrm{C}$ losses occur not only due to the decrease in biological processes, but also due to erosion.

The higher contents of TOC $(0-5 \mathrm{~cm})$ and TN $(0-10 \mathrm{~cm})$ found in the E45 area can be attributed to the annual application of swine waste for a long period. In other words, as the E45 area is older, it was subjected to a greater addition of organic residues via manure and plant biomass, creating in the surface layer an environment of greater accumulation and/or preservation of these attributes. These results are corroborated by the increase in POC content in the areas from 35 to 45 years for the same depths.

By comparing the results of TOC and TN obtained in this study to those of other studies in the literature (PICCOLO et al., 2008; DENARDIN et al., 2014), it is possible to observe reductions of TOC in the surface layer $(0-10 \mathrm{~cm})$ of 47 and $62 \%$, respectively, between yerba mate areas and adjacent native forest. This shows that the management used in cultivated areas did not promote major changes, as there was only a reduction of at most $14 \%$ in the E45 area $(5-10 \mathrm{~cm})$. The results of TOC and $\mathrm{N}$ indicate that the input of organic fertilization may have contributed to a smaller reduction, because similar results of TOC between E35 and NF were verified in the surface layers. Analyzing the effects of swine waste application under different cropping systems, Steiner et al. (2012) and Castro Filho et al. (2003) found an increase in soil organic carbon content.

The results of organic carbon of the particle-size fractions of SOM suggest that the higher POC contents in the native forest may be related to the characteristics of this area, which produces greater input of organic material from different plant species in a more favorable environment for preservation, hence contributing to the increase and/or maintenance of this labile fraction of soil C. Some studies in the literature (GUARESCHI et al., 2012; DINIZ et al., 2015) have also associated the increase in these fractions with the characteristics of the area as a possible explanation for the greater supply of POC in the reference forest areas.

The higher POC contents observed in the E45 area can be attributed to the longer cultivation time and addition of organic fertilization in the E45 area compared to the E35 area. The organic matter present in the liquid swine waste is predominantly composed of labile organic carbon (ANGERS et al., 2010) and its annual application throughout this growing period can contribute to the increase and maintenance of this soil organic matter compartment. Unlike the results observed in this study, Andrade et al. (2016) and Rauber et al. (2017) found lower POC contents in areas of yerba mate (20 years of monoculture) compared to native forest under Nitossolos (Ultisols). The differentiated pattern of the results of the present study can be attributed to several reasons, such as different soil types, different managements and especially the time of adoption of monoculture. As the MAOC 
values did not vary between the areas of cultivation, it can be inferred that the main compartment of organic matter being influenced by the management is the POC.

The higher MAOC contents observed in the area of native forest $(5-10 \mathrm{~cm})$ may be influenced by the higher deposition of organic residues with different $\mathrm{C} / \mathrm{N}$ ratios in this area, which contributes to the formation of a more recalcitrant organic matter. In addition, the root system of plants in this area may have released more organic material by rhizodeposition in this layer, with consequent formation of MAOC (CARMO et al., 2012). On the other hand, the lower MAOC contents in comparison to the cultivated areas at $10-20 \mathrm{~cm}$ depth may be due to the process of formation of these particle-size fractions because, for higher MAOC contents to occur in the soil, there must be greater decomposition of POC contents, for later association with soil minerals in the clay and silt fractions (Figueiredo et al., 2010).

The similar results of MAOC between the cultivated areas at all depths show that, except for the $0-10 \mathrm{~cm}$ layer, this recalcitrant fraction of TOC has not yet been subjected to significant reductions when compared to the native forest area, thus evidencing that the yerba mate monoculture of 45 years is influencing only the organic matter fractions of greater lability. This shows that this fraction of organic matter is highly stabilized, being little influenced by management systems (CARMO et al., 2012). However, this fraction of organic matter does not always function as a good indicator of the effect of management on soil properties, since changes in the stock of this organic matter compartment take many years to be detected (CARMO et al., 2012).

As observed for TOC and N contents, POC and MAOC contents are also decreasing in subsurface, influenced by the lower supply of $\mathrm{C}$ in subsurface.

Regarding the results of organic carbon of the chemical fractions of the SOM, the reduction in the contents and absence of significance for the fulvic acid fraction (FAF), observed in subsurface in all areas, may be related to the fact that this fraction is very soluble and less labile, and its dynamics of formation and decomposition is more accelerated compared to the other fractions.

The higher contents of the humic acid fraction (HAF) at the $0-40 \mathrm{~cm}$ depth observed in the native forest area, compared to the cultivated areas, are due to the greater supply in quantity and quality (different $\mathrm{C} / \mathrm{N}$ ratios) of organic material (DINIZ et al., 2015). Generally, in areas with higher C supply via shoots and roots and with higher $\mathrm{C} / \mathrm{N}$ ratio, there is a predominance of more recalcitrant fractions, such as C-HAF and C-HUM (DINIZ et al., 2015). The higher contents of this fraction in the E45 area $(0-5 \mathrm{~cm})$, compared to E35, may be related to its higher clay content (Table 1), which may be assisting in the greater stability of this fraction in the soil.

The absence of difference in the humin fraction (HUM) contents between the areas corroborates the MAOC data observed in the cultivated areas, which indicate that these more stabilized fractions are not being subjected to changes as a function of management time, except for the most superficial layer of the soil, which showed reductions of 25 and $14 \%$ in the humin fraction of the areas E35 and E45, respectively, in comparison to the native forest. In this case, the humin fraction was a more sensitive indicator than MAOC to represent the changes in the most stabilized fraction of TOC imposed by the cultivation of yerba mate in the surface layer of the soil evaluated.

Through the PCA it is possible to infer that the time of management with swine waste is causing modifications in SOM compartments, with positive effects on some of its fractions, as certain points of the E45 area (longer management time) tend to approach the native forest area (Figure 1A, 1C and 1D), which is related to higher values of the SOM compartments. In addition, it is important to highlight that the influence of crops, especially E35, on the SOM compartments, occurs with greater intensity, reducing the values of these attributes in the most superficial layers of the soil $(0-5$ and 5-10 $\mathrm{cm})$, because in these layers these compartments are more associated with native forest, while in deeper layers $(10-20$ and $20-40 \mathrm{~cm})$ they are more dispersed between the cultivation areas and the native forest (Figure 1C and 1D). HAF was the most responsive SOM compartment, as in all soil layers it contributed to the separation between the areas of cultivation and native forest, showing a high correlation $(\geq \pm 0.8)$ with the main axis (axis 1$)$.

\section{CONCLUSIONS}

- For having longer cultivation time and addition of organic fertilization, the E45 area had higher contents of TOC, N and POC in comparison to the E35 area, and similar values of these attributes were observed in the forest area at some depths.

- The more stable carbon fractions (MAOC and humin) did not vary between the cultivated areas (E35 and E45); however, there were reductions of 25 and 14\% (HUM 0-5 cm) and 12 and 21\% (MAOC 5-10 cm) in these fractions, respectively, compared to the native forest.

- There was no difference between the evaluated areas for FAF, but HAF values were higher in the native forest area than in the cultivated areas. 


\section{REFERENCES}

ALEGRE, J.; MONTOYA, L.; CORREA, G. Geração das curvas alométricas para avaliar as reservas de carbono em plantios de erva mate (Ilex paraguariensis St. Hill), no sul do Brasil. Boletim n. 33. Embrapa Florestas. Colombo, PR. 2007.

ANDRADE, A.P.; RAUBER, L.P.; MAFRA, A.L.;BARETTA, D.; ROSA, M.G.; FRIEDERICHS, A.;MAFRA, M.S.H.; CASARA, A.C. Changes in physical properties and organic carbon of a Kandiudox fertilized with manure. Ciência Rural, Santa Maria, v.46, n.5, p.809-814, 2016.

ANGERS, D. A.; CHANTIGNY, M. H.; MACDONALD, J. D.; ROCHETTE, P.; COTE, D. Differential retention of carbon, nitrogen and phosphorus in grassland soil profiles with long-term manure application. Nutrient Cycling in Agroecosystems, Heidelberg, v. 86, n. 2, p. 225-229, 2010.

BATISTA, I.; CORREIA, M. E. F.; PEREIRA, M. G.; BIELUCZYK, W.; SCHIAVO, J. A.; MELLO, N. A. de; ROWS, J. R. C. Teores e estoque de carbono em frações lábeis e recalcitrantes da matéria orgânica do solo sob integração lavoura-pecuária no bioma Cerrado. Semina: Ciências Agrárias, Londrina, v. 34, n. 6, p. 3377-3388, 2013.

BENITES, V. M.; MADARI, B.; MACHADO, P. L. O. A. Extração e fracionamento quantitativo de substâncias húmicas do solo: um procedimento simplificado de baixo custo. Rio de Janeiro: Embrapa Solos, 2003. (Comunicado Técnico, 16).

BEUTLER, S. J.; PEREIRA, M. G.; LOSS, A.; PERIN, A.; SILVA, C. F. Edaphic attributes of a crop-livestock integration system in the cerrado biome. Revista Caatinga, Mossoró, v.29, n.4, p.892-90, 2016.

CAMBARDELLA, C.A.; ELLIOTT, E.T. Particulate soil organic matter changes across a grassland cultivation sequence. Soil Science Society of America Journal, Madison, v.56, p.777-783, 1992.

CARMO, F. F.; FIGUEIREDO, C. C.; RAMOS, M. L. G.; VIVALDI, L. J.; ARAÚJO, L. G. Frações granulométricas da matéria orgânica em Latossolo sob plantio direto com gramíneas. Bioscience Journal, Uberlândia, v. 28, n. 3, p. 420-431, 2012.

CORRÊA, J.C.; BARILlI, J.; REBELlATTO, A.;VEIGA, M. Aplicações de dejetos de suínos e as propriedades do solo. Circular técnica, n58. 18p. 2012.

DENARDIN, R.B.D.; MATTIAS, J.L.; WILDNER, L.P.; NESI, C.N.; SORDI, A.; KOLLING, D.F.; BUSNELLO, F.J.; CERUTTI, T. Estoque de carbono no solo sob diferentes formações florestais, Chapecó - SC. Ciência Florestal, Santa Maria, v. 24, n. 1, p. 59-69, 2014.

DINIZ, A.R.; PEREIRA, M.G.; BALIEIRO, F.C.; SILVA, E.V.; SANTOS, F.M.; OLIVEIRA, A.B.; CRUZ, R.B. Frações da matéria orgânica do solo em plantios clonais de seringueira em regiões costeiras do Brasil. Revista de la Facultad de Agronomía, La Plata, v.114, n.1, p.106-114, 2015.

DONAGEMA, G. K.; CAMPOS, D. V. B. de; CALDERANO, S. B.; TEIXEIRA, W. G.; VIANA, J. H. M. (Org.). Manual de métodos de análise de solos. 2. ed. Rio de Janeiro: Embrapa Solos, 2011. 230 p.

FIGUEIREDO, C. C. de; RESCK, D. V. S.; CARNEIRO, M. A. C. Labile and stable fractions of soil organic matter under management systems and native cerrado. Revista Brasileira de Ciência do Solo, Viçosa, v. 34, n. 3, p. 907-916, 2010.

GAZOLLA, P. R; GUARESCHI, R. F.; PERIN, A.; PEREIRA, M. G.; ROSSI, C. Q. Frações da matéria orgânica do solo sob pastagem, sistema plantio direto e integração lavoura-pecuária. Semina: Ciências Agrárias, Londrina, v. 36, n. 2, p. 693-704, 2015.

GUARESCHI, R. F.; PEREIRA, M. G.; PERIN, A. Deposição de resíduos vegetais, matéria orgânica leve, estoques de carbono e nitrogênio e fósforo remanescente sob diferentes sistemas de manejo no Cerrado Goiano. Revista Brasileira de Ciência do Solo, v.36, p.909-920, 2012.

PICCOLO, A.G.; ANDRIULO, A.E; MARY, B. Changes in soil organic matter under different land management in missiones province (Argentina). Scientia Agricola, Piracicaba, v.65, n.3, p.290-297, 2008.

RAUBER, L.P.; ANDRADE, A.P.; MAFRA, A.L. Soil organic carbon stocks in granulometric fractions under use and management systems with swine and poultry manure. Brazilian Journal of Agriculture, Piracicaba, v.92, n.2, p. 101-114, 2017. 
SANTOS, D. C.; FARIAS, M. O.; LIMA, C. L. R.; KUNDE, R. J.; PILLON, C. N.; FLORES, C. A. Fracionamento químico e físico da matéria orgânica de um Argissolo Vermelho sob diferentes sistemas de uso. Ciência Rural, Santa Maria, v. 43, n. 5, p. 838-844, 2013.

SWIFT, R.S. Organic matter characterization. In: Sparks, D.L.; Page, A.L.; Helmke, P.A.; Loeppert, R.H.; Soltanpour, P.N.; Tabatabai, M.A.; Johnston, C.T.; Sumner, M.E. (Eds.) Methods of soil analysis: chemical methods. Vol. 3. Soil Science Society of America; American Society of Agronomy, Madison. (SSSA. Book Series, 5). p. 1011-1020. 1996.

STEINER, F.; PIVETTA, L.A.; ZOZ, T.; PINTO JUNIOR, A.S. Estoque de carbono orgânico no solo afetado por adubação orgânica e sistemas de culturas no Sul do Brasil. Semina: Ciências Agrárias, Londrina, v. 33, suplemento 1, p. 2775-2788, 2012.

VOGT, G.A.; NEPPEL, G.; SOUZA, A.M. A Atividade ervateira no planalto norte catarinense: a indicação geográfica como alternativa para a (re)valorização do produto erva-mate. Desenvolvimento Regional em Debate, Canoinhas, v. 6, n. 2, ed. esp., p. 64-87, 2016.

YEOMANS, J. C.; BREMNER, J. M. A rapid and precise method for routine determination of organic carbon in soil. Communications in Soil Science and Plant Analysis, Philadelphia, v. 13, n. 13, p. 1467-1476, 1988. 